Article

\title{
Factors Affecting the Capital Cost of Prefabrication-A Case Study of China
}

\author{
Hong Xue ${ }^{1, *}$, Shoujian Zhang ${ }^{2}$, Yikun $\mathrm{Su}^{3}$ and Zezhou $\mathrm{Wu}^{4}$ \\ 1 School of Management, Harbin Institute of Technology, Harbin 150001, China \\ 2 School of Civil Engineering, Harbin Institute of Technology, Harbin 150001, China; zhangsj@hit.edu.cn \\ 3 School of Civil Engineering, Northeast Forestry University, Harbin 150040, China; suyikun@nefu.edu.cn \\ 4 Department of Construction Management and Real Estate, College of Civil Engineering, \\ Shenzhen University, Shenzhen 518060, China; wuzezhou@szu.edu.cn \\ * Correspondence: xuehong@stu.hit.edu.cn
}

Received: 26 July 2017; Accepted: 21 August 2017; Published: 24 August 2017

\begin{abstract}
As a sustainable construction method, prefabrication has become popular in many nations. However, there are many challenges for prefabrication, especially in terms of cost. Previous studies have revealed that higher capital cost was the most important barrier to the implementation of prefabrication. Thus, the objective of this study is to explore and evaluate the critical factors affecting the capital cost of prefabrication and examine how cost management may be affected by the "experience", "corporate responsibility", and "participant function" as a fix independent factors. To achieve the research objective, semi-structured interviews were conducted with 11 experts for the development of the questionnaire. Then, a questionnaire survey was conducted to investigate the significance of 49 factors related to prefabrication capital cost. The survey results revealed that "Specification and standards for prefabricated building design", "Related experience of manager", and "Rationality of precast component split" were the most critical factors. In addition, "experience", "corporate responsibility", and "participant function" had significant impact on the evaluation of capital cost factors. The findings can facilitate developing a benchmark framework for exploring the factors affecting the capital cost of prefabrication in China.
\end{abstract}

Keywords: prefabrication; sustainability; mean analysis; capital cost; factors

\section{Introduction}

Traditional on-site construction, as a common method, has been criticized because of its inherent drawbacks, such as long construction time [1,2], low productivity [3], external weather constraints [4], waste of resource, environmental pollution [5], poor safety, etc. Prefabrication has been introduction as a major mode for promoting environment and sustainability performance in the construction industry [6]. Prefabrication has various terms such as industrialized construction, prefabricated construction, assembly, modular construction, mass production, modern method of construction, and off-site construction. The main contexts of these terms refer to three common activities, i.e., production precast components at a factory, delivering precast components to on-sites, and assembling precast components to form buildings $[7,8]$. Prefabrication as a sustainable method that offers great benefits, such as reduction in waste [9], time, labor [10], cost, health and safety risks [11], and environmental pollution; and improvement in profits, predictability, and life performance [12], has become popular in many nations. Meanwhile, governments in some countries are confronted with problems, such as demographic dividend disappearing, frequent security incidents [7], and serious waste of resources and environmental pollution [13]. In China, the government is promoting the prefabrication in engineering construction through a series of incentive measures, such as floor area allowance, cash 
bonus and tax exemption [14]. The Chinese government has expected the precast ratio (by volume) in construction industry to reach $30 \%$ by 2020 .

However, prefabrication was hindered by many barriers that are involved in the engineering construction process [15]. As a new method, the technical issues of prefabrication are likely to bring about some quality problems, such as weak performance of joint nodes [16] and poor thermal insulation performance of precast facades [8]. Prefabrication lacks standards and specifications, especially for the design, production and installment processes, and thus is affiliated with various problems, such as mismatching of precast components (PC), on- and off-site components and incapability of mass production [17-19]. Furthermore, the capital cost of prefabrication has been estimated 10-20\% higher than on-site construction [20]. Specifically, a survey revealed that the capital cost of the prefabrication was CNY200-300/ $\mathrm{m}^{3}$ higher than that of the on-site construction in China [7]. Most of the project clients take cost factors into account when they choose a construction method [21], and 85\% of the clients refused to adopt prefabrication because of the higher capital cost [22]. Meanwhile, the contractors might not take prefabrication if the price remains higher than traditional on-site [23]. Financial incentives were implemented to buffer the impact of higher capital cost, such as tax allowance, floor area bonus, cash allowance [16], etc. in China. However, prefabrication was still at its infancy stage, and the preferential policies had only a temporary promotion, and has not resulted in a sustainable increase in the use of prefabrication. Previous studies have revealed that the higher capital cost was still the most significant barrier to the prefabrication development [24]. Factors affecting prefabrication promoting have been explored while the significance of these factors and the potential to improve prefabrication project management have been reported. Meanwhile, the benefits of the whole life cost of prefabrication have been discussed. The inscape of prefabrication cost has been analyzed and classified. However, few studies have explored the causes of incremental capital cost of prefabrication compared to traditional on-site construction, especially for the process-oriented (consisting of three main process: design, production and transportation and installation processes) and object-oriented cost management strategies (including main stakeholders, e.g., clients, designers, supervisors, contractors and PC manufacturers; refers to labor, materials, machinery consumption). The cost of prefabrication has been anecdotal or fragmented with isolated studies. Hence, this study aims to explore factors affecting the incremental capital cost of prefabrication compared to traditional on-site construction through a questionnaire survey and interviews. The research objectives of this study are to explore the causes of incremental capital cost of prefabrication systematically; rank the relative significance of the factors; propose process-oriented and object-oriented cost management strategies; and examine how cost management is affected by the "experience", "corporate responsibility", and "participant function" as fix independent factors.

\section{Literature Review}

The Modular Building Institute defines "prefabrication" as the process of manufacturing and assembling the major building components at remote factory, transport to construction site, then installation [25]. Prefabrication may be low on operation and maintenance, and for the whole life cost [26], but high on capital cost. However, stakeholders have paid more attention to interests of capital investment, overlooking the whole life interests. Hence, capital cost was the focus of promoting prefabrication development. There are various types of prefabricated buildings. Wajiha [25] found that the cost and productivity benefits were not influenced by building type, and are likely to be consistent across all building types. Thus, the impact of building type on cost was not examined in this study.

\subsection{Barriers to Cost-Saving for Prefabrication}

Previous studies on prefabrication have been focused on technical feasibility [27,28], barriers [29], quality controlling [8], environmental benefits [30], risk management [19,31,32], organization management [33], etc. As for cost management issues in prefabrication, Rahman [34] found that the contractors were sensitive to cost, and higher cost was one of the most significant barriers when 
they chose the construction method. Chen [20] indicated that capital cost of prefabricated building was $10-20 \%$ higher than the traditional on-site construction. Mao [7] argued that higher cost of PC consisted of material cost, labor cost, machinery cost, factory cost, land cost, management cost, and mold cost. Arashpour [33] found that cross-training cost of off-site construction was an additional cost compared with traditional on-site. Arashpour et al. [35] claimed that producing a large variety of PC involved more investment because prefabrication systems had no tendency towards repetitiveness. Furthermore, insufficient qualified civil engineers and specialized architects also resulted in poor design, plant and production management, and erection practices [36]. Blismas et al. [30] suggested that prefabrication designed in a "traditional" method tended to overlook the characteristics of prefabrication. Design alteration resulted in unreasonable time and cost for PC manufacturers and contractors [15]. Moreover, inefficiency in the information flow between the designers and PC manufacturers can bring about reworks [21,37]. Asri [38] reported that labor productivity, skilled worker's wages, construction project size and construction time significantly influenced cost performance. Higher capital cost and not economies of scale were primary causes of higher cost of the prefabrication. Moreover, complexity between joints and incapability of freezing the design early resulted in additional cost compared with traditional on-site [39]. Khalili [40] showed that mold types and turnover rate were influential to PC cost. Jaillon and Poon [41] found that the transportation cost of PC made the initial cost higher. Arashpour [35] indicated that workflow variability was likely to cause cost risk in the interdependent networks.

\subsection{Drivers for Cost-Saving for Prefabrication}

However, a study revealed that $93 \%$ of the contractors said that they achieved cost savings benefiting from better communication between the designers and contractors. The cooperation among the participants was helpful to project management [42,43]. Pan suggested that standardization design promoted the mass production, and that economies of scale can reduce the cost of prefabrication [22]. This is because standardization can improve the proficiency and productivity of the workers, and reduce the labor cost $[18,44]$. Isaac [18] found that standardized design was a primary way to solve the mismatching between on-site and off-site joints. Kim [45] stressed that collaborative efforts were effective to lower down the cost of total supply chain. Compared with the private sector, Jaillon [46] found that cost of prefabrication built in state-owned enterprises was 10\% higher than that of the traditional construction, while cost of the prefabrication in the private sector was only $2 \%$ higher. Chiang [15] found that the quantity was a critical factor reducing cost by achieving the scale economy. Jaillon [5] believed that repetition ratio of PC was essential to meet the quantity for economic scale. Meanwhile, management mode, knowledge management and systematic management can promote cost management. Hill [47] found that management mode based on the process-oriented strategies can reduce cost. The past experience of clients can be used for project management to reduce cost [21]. Winch [48] suggested that improving awareness in various phases of industrialized building can increase the economic benefits of the project. The level of knowledge, awareness and experience of developers had effect on the new construction method [42]. Alazzaz [49] found that employee empowerment can reduce time and cost, and enhance quality. Furthermore, specification of design, procurement, and construction method had an active effect on cost management [50]. Efficiency learning, technological innovation, "in-house" building management, national and international partnering can increase the profits of project management [44]. Moreover, Gann [51] reported that the role of professional institutions was important to the uptake of prefabrication.

Hence, capital cost of prefabrication can be affected by composite and various factors, and cost management is a systematic, complex, and dynamic process. This study aims to explore the factors affecting the incremental capital cost of prefabrication, evaluate the relative significance of the factors, propose process-oriented and object-oriented cost management strategies for promoting prefabrication development [16,33], and examine how cost management is affected by the "experience", "corporate responsibility", and "participant function" as fix independent factors. 


\section{Research Methodology}

\subsection{Mean Analysis}

Mean analysis has been widely used to analyze the differences between groups. The independent sample $t$-test has been commonly used to examine whether the mean values of a specific variable from two independent groups are significantly consistent, or whether they are significantly different $[16,52]$. The one-way ANOVA (analysis of variance) is usually used to check whether the mean values of a specific variable from more than two independent groups are significantly different [8]. For the independent sample $t$-test, two steps were performed in our study: (1) descriptive statistics; and (2) independent sample $t$-test: (1) Levene's test for equality of variance; and (2) $t$-test for equality of means. In the independent sample $t$-test, the null hypothesis $\mathrm{H} 0$ is proposed: The mean values of the two groups are the same. For the one-way ANOVA, four steps were conducted in our study: (1) descriptive statistics; (2) test of homogeneity of variances, i.e., Levene's test for equality of variance; (3) ANOVA for equality of means; and (4) post-hoc tests, i.e., multiple comparisons. In the one-way ANOVA, our study proposed the null hypothesis H0: The mean values of the groups are the same. Descriptive statistics was used to obtain mean and Standard Deviation (SD) values. The Levene's test should be carried out before the independent sample $t$-test or the one-way ANOVA to testify the variance is homogeneous (significance (sig.) < 0.05). The independent sample $t$-test and one-way ANOVA were used to explore the effect of grouping variables on factors: sig. $>0.05$ indicates the grouping variable has an influence on the factor. The post-hoc tests were used to search the specific reasons for the deviation of groups.

\subsection{Calculation of Prefabrication Capital Cost}

This study [48] investigated the capital cost of prefabrication based on process-oriented and object-oriented construction indicating three types of factors: the whole stakeholders (i.e., clients, designers, supervisors, contractors, and PC manufacturers); all material consumption elements (i.e., workers, materials, and machines); and the whole construction process (i.e., design, production, transportation and on-site installation stages). The prefabrication capital cost $(C)$ consists of three parts: production $\operatorname{cost}\left(C_{p}\right)$, transportation $\operatorname{cost}\left(C_{t}\right)$ and installation cost $\left(C_{i}\right)$. Thus, the prefabrication capital cost can be calculated using Equation (1).

$$
C=C_{p}+C_{t}+C_{i}+u c
$$

where $u c$ represents cost deviations, resulting in incremental costs due to contingencies; $C_{p}$ is determined by the design and production stages; $C_{t}$ is determined by the design, production, transportation and on-site installation stages [53]; and $C_{i}$ is determined by the design, production and on-site installation stages. The transport of PC is usually completed by PC manufacturers. Hence, the capital cost management process is based on three parts: the design stage, the production and transportation stage, and the on-site installation stage. The study attempts to explore the factors affecting the incremental capital cost of prefabrication compared with the traditional on-site construction, but excludes the cost factors impacting both prefabrication and traditional on-site construction methods, such as expenses of labor and materials, inflation, land acquisition fee, taxes $[7,20]$, etc.

\subsection{Data Collection}

Literature reviews was used to identify the factors affecting the capital cost of prefabrication (Table 1). Semi-structured interviews were conducted with the professionals who were experienced in prefabrication project management, to assure the comprehensiveness of the cost factors. Then, the preliminary questionnaire was designed, and tested in the pilot study. The finalized questionnaires were distributed to professionals experienced in project management. SPSS (Statistical Product and Service Solutions) 20.0 software (IBM SPSS Company, Chicago, USA) was used to test the validity of 
date collected. Mean analysis was used to analyze the difference among the factors [16]. Furthermore, the independent sample $t$-test and one-way ANOVA were undertaken to check the consistency of the views among different groups.

Table 1. Previous studies on prefabrication cost management.

\begin{tabular}{|c|c|c|}
\hline Stage & Factors & Source \\
\hline design & $\begin{array}{l}\text { repetitiveness, qualified civil engineers, specialized } \\
\text { architects, poor design, design alteration, unable to } \\
\text { freeze the design early on, standardization design, } \\
\text { repetition ratio of PC, experience, specification of design }\end{array}$ & $\begin{array}{l}\text { Arashpour [35], Polat [36], } \\
\text { Gibb [21], Blismas [30], Pan [39], } \\
\text { Pan [22], Isaac [18], Chiang [15], } \\
\text { Jaillon [5], Gibb [21], Matic [54] }\end{array}$ \\
\hline production & $\begin{array}{l}\text { higher capital cost, economies of scale, mold types, } \\
\text { turnover rate, proficiency of the workers, employee } \\
\text { empowerment, procurement method, mass production }\end{array}$ & $\begin{array}{l}\text { Asri [38], Khalili [40], Isaac [18], } \\
\text { Poirier [44], Alazzaz [49], Mao [7], } \\
\text { Matic [54] }\end{array}$ \\
\hline transportation & transportation cost of PC, collaborative efforts, distance & Jaillon and Poon [41], Kim [45] \\
\hline $\begin{array}{l}\text { on-site } \\
\text { installation }\end{array}$ & $\begin{array}{l}\text { plant and production management, erection practices, } \\
\text { labor productivity, skilled worker's wages, scale of } \\
\text { construction projects, construction time, complexity } \\
\text { between joints, mismatching between on and off-site } \\
\text { joints, experience, project management }\end{array}$ & $\begin{array}{l}\text { Polat [36], Asri [38], } \\
\text { Arashpour [33], Pan [39], } \\
\text { Isaac [18], Gibb [21] }\end{array}$ \\
\hline $\begin{array}{l}\text { the whole } \\
\text { process }\end{array}$ & $\begin{array}{l}\text { material cost, labor cost, machinery cost and factory, } \\
\text { mold cost, training, communication, cooperation, } \\
\text { management mode, knowledge management, } \\
\text { technological innovation, professional institutions }\end{array}$ & $\begin{array}{l}\text { Mao [7], Arashpour [33], } \\
\text { Jaillon [41], Polat [42], David [43], } \\
\text { Hill [47], Gann [51] }\end{array}$ \\
\hline
\end{tabular}

\subsubsection{Factors Affecting the Capital Cost of Prefabrication}

Based on the previous studies in Table 1, semi-structured interviews were designed and conducted with 11 professionals, including 3 clients, 2 designers, 1 supervisor, 2 constructors, 2 PC manufactures and 1 professor, who were experienced in prefabrication. Each interview lasted between $30 \mathrm{~min}$ and $1.5 \mathrm{~h}$. All interviews were conducted between October 2016 and November 2016. The results showed that PC, as the basic element of prefabrication, played an important role in cost management [7]. Moreover, coordination among the stakeholders also had a significant effect on cost management in the whole construction process [54]. Based on the interview results, the factors affecting the capital cost of prefabrication were summarized in Table 2.

Table 2. Factors affect the capital cost of prefabrication.

\begin{tabular}{lll}
\hline Stage & Code & Factors \\
\hline & FD1 & Coordination between designer and builder \\
FD2 & Coordination between designer and PC manufacturer \\
FD3 & Coordination between designer and contractor \\
FD4 & Specification and standards for prefabricated building design \\
FD5 & Standard component catalogue of prefabricated building \\
FD6 & Design pattern of prefabricated building \\
FD7 & Diversity of prefabricated building structure \\
FD8 & Related experience of designer \\
FD9 & Collaborative capacity among professional designers \\
FD10 & Design level of teamwork \\
FD11 & Rationality of PC split \\
& FD12 & Node coordination between PC and on-site component \\
FD13 & Coordination of connection nodes of PC components \\
FD14 & Reuse ratio of standard components \\
& FD15 & Type of building structure \\
FD16 & Third party of drawing audit organization \\
\hline
\end{tabular}


Table 2. Cont.

\begin{tabular}{|c|c|c|}
\hline Stage & Code & Factors \\
\hline \multirow{23}{*}{ Production and Transportation stage } & FPT1 & Specification and Standards for PC production \\
\hline & FPT2 & Design plan for PC production line \\
\hline & FPT3 & Order quantity of PC \\
\hline & FPT4 & Capacity of production line in PC \\
\hline & FPT5 & Depreciation of fixed assets \\
\hline & FPT6 & Maintenance of mechanical installation \\
\hline & FPT7 & Production technology of PC \\
\hline & FPT8 & Technical standards system of prefabricated building \\
\hline & FPT9 & Attrition rate of reinforcement \\
\hline & FPT10 & Additional reinforcement due to connection points \\
\hline & FPT11 & Curing condition to PC \\
\hline & FPT12 & Reuse rate of PC mold \\
\hline & FPT13 & Types and specifications in PC mold \\
\hline & FPT14 & Scrap quantity of mold \\
\hline & FPT15 & Number of professionals \\
\hline & FPT16 & Efficiency of production worker \\
\hline & FPT17 & Turnover rate of production worker \\
\hline & FPT18 & Training cost of production workers \\
\hline & FPT19 & Storage cost of PC in precast plant \\
\hline & FPT20 & Selection of transport machinery used for PC \\
\hline & FPT21 & Transportation and shipment forms of PC \\
\hline & FPT22 & Transport distance \\
\hline & FPT23 & Attrition rate of PC component in transportation \\
\hline \multirow{10}{*}{ On-site Installation stage } & FC1 & Related experience of manager \\
\hline & FC2 & Coordination of all types of work on site \\
\hline & FC3 & Operant level on installation personnel \\
\hline & FC4 & Technical specifications and standards for PC installation \\
\hline & FC5 & Storage condition of PC on-site \\
\hline & FC6 & Mechanical efficiency of tower crane \\
\hline & FC7 & Hoisting procedure of PC \\
\hline & FC8 & Redundancy of installation process \\
\hline & FC9 & The scale of prefabricated construction project \\
\hline & FC10 & Rental fee of installation equipment \\
\hline
\end{tabular}

\subsubsection{Questionnaire Design}

Based on the cost factors in Table 2, a questionnaire was designed to collect professionals' views on the relative significance of factors. The effectiveness of the questionnaire has been tested through a pilot study. The questionnaire was developed and finalized for distribution to professionals. Those professionals consisted of 20 experts experienced in prefabrication, which were registered under the Ministry of Housing and Urban-Rural Development of the People's Republic of China (MOHURD). The sample covered a wide range of stakeholders to ensure representation of group views, including 5 clients, 3 designers, 2 supervisors, 5 constructors, 3 PC manufactures and 2 professors. All the professionals came from the China Construction Industry Association (CCIA) and were experienced in prefabrication, which ensured the authority and reliability of this study. The five-point Likert scale method was used to measure the degree of significance of factors [52], in which " 1 " refers to "negligible", "2" "insignificant", "3" "average", " 4 " "significant" and " 5 " "most important". To ensure the reliability and validity of the survey, the questionnaire was distributed to the professionals who were experienced in project management. The questionnaire was distributed through multiple channels including field investigation, e-mail and online sojump [55]. The targeted regions were wide, including the cities of Beijing, Shenzhen, Shanghai, Chongqing, Ji'nan, Shenyang, Wuhan, Guangzhou, Xi'an, Nanjing, and Qingdao, where prefabrication is developing rapidly. The "snowball" sampling method was adopted through individual contacts in order to increase the number of responses. The survey was conducted during the period from 15 December 2016 to 5 May 2017. A total of 389 questionnaires were distributed, and 191 were received, yielding a response rate of $49.1 \%$. This rate was consistent with the norm of $20-30 \%$ in construction management surveys [56]. In this study, the authors limited the 
scope to construction personnel including top management, middle management, first-line managers, and technician. Finally, based on the selection criteria, a sample of 178 respondents were selected for analysis, with an effective rate of $93.2 \%$.

\subsection{Descriptive Statistics}

SPSS 20.0 software was used to test the validity of the questionnaire. The coefficient of Cronbach's $\alpha$ is an important index to judge the reliability of the data from the questionnaire. The following outcomes are commonly accepted for the value of Cronbach's $\alpha>0.9$, Excellent; $\alpha>0.8$, Good; $\alpha>0.7$, Acceptable; $\alpha>0.6$, Questionable; $\alpha>0.5$, Poor; and $\alpha<0.5$, Unacceptable [8]. In this survey, $\alpha$ was 0.941 , which suggested the data were reliable and valid.

Among the respondents, 30\% were clients (firm 1); $16 \%$ were designers (firm 2); $11 \%$ were supervisors (firm 3); $16 \%$ were PC manufacturers (firm 4); $20 \%$ were on-site contractors (firm 5); and 7\% were researchers (firm 6). Furthermore, $10 \%$ were top managers (group 1); $27 \%$ were middle managers (group 2); $26 \%$ were first-line managers (group 3); and 37\% were technician (group 4). Meanwhile, $72 \%$ of the interviewees had both knowledge and experience [57] (series 1) in prefabrication and $28 \%$ were hade knowledge and practical experience in on-site construction but not in prefabrication (series 2). The survey revealed that $81 \%$ of the surveyed projects were residences. Meanwhile, $45 \%$ were reinforced concrete structure; $33 \%$ were frame-shear wall structure; and $22 \%$ were steel structure. Precast ratio (by volume) has been often used as a standard for evaluating prefabrication development (Figure 1) [41]. The survey investigated that the highest proportion (31.3\%) of the precast ratio was $30 \%$. The phenomenon was attributed to that the government required that the precast ratio to reach $30 \%$ by 2020 . The ratio of $80 \%$ was the second highest proportion $(12.5 \%)$, mainly rooted in steel structure building. The precast ratio of steel structure systems was higher than that of reinforced concrete systems, because steel is easy to be prefabricated [16].

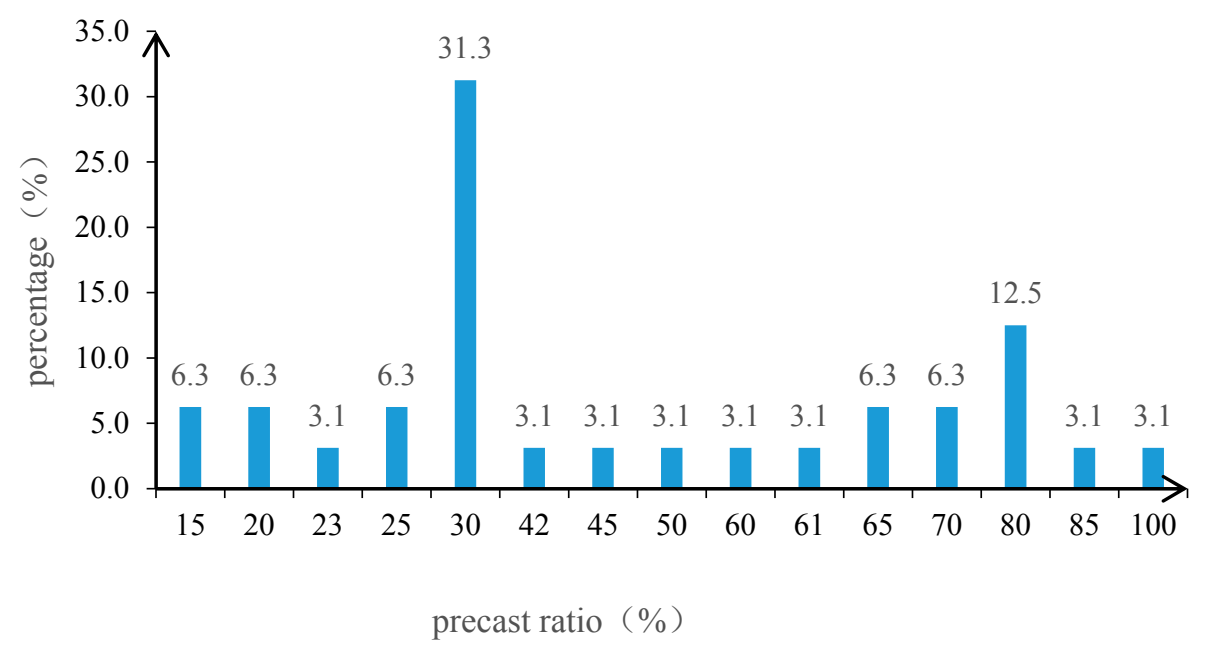

Figure 1. Statistics information on precast ratio (\%).

The study counted general PC used in prefabrication (Figure 2): $90.5 \%$ were precast staircase; $85.7 \%$ were precast facades; and $69.0 \%$ were semi-precast slab. In addition, $9.5 \%$ were integral vacuum toilet; and $4.8 \%$ were integrated kitchen. This was because the whole kitchen and toilet tended to have waterproof and water leakage problems. 


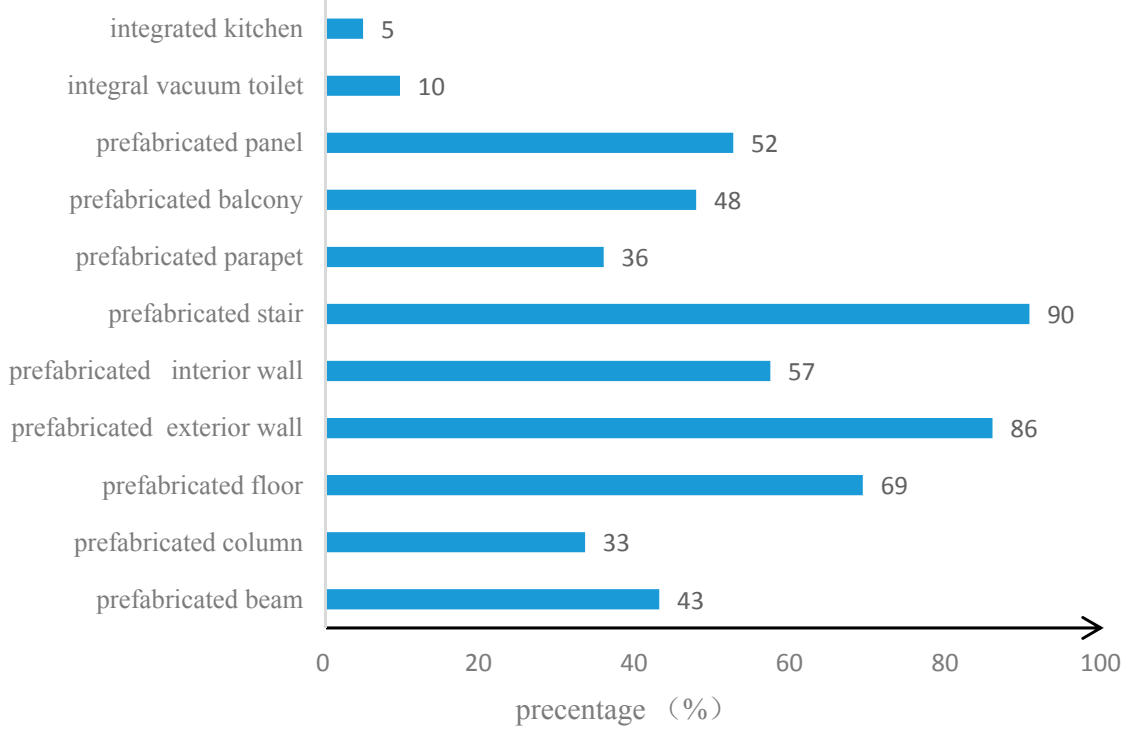

Figure 2. Precast components.

\section{Research Findings}

Mean analysis has been a common method used to analyze the difference of factors [16]. The survey revealed that mean value of the whole 49 factors were over than 3.0, which represented the whole factors influenced capital cost of prefabrication, among which the maximum mean value was 4.36, and the minimum mean value was 3.02 (Table 3). The 10 most important factors were "Specification and standards for prefabricated building design", "Related experience of manager", "Rationality of PC split", "Capacity of production line in PC", "Operant level on installation personnel", "Order quantity of PC", "Coordination between designer and PC manufacturer", "Collaborative capacity among professional designers", "Coordination of connection nodes of PC components", and "Related experience of designer". "Specification and standards for prefabricated building design" were the most important factors among the 49 factors, which was consistent with the actuality in China [7]. "Design standardization" was the primary task for promoting the prefabrication. "Design standardization" was one of the benefits for economics of scale, which was the fundamental way to reduce the cost of prefabrication [18]. However, "Attrition rate of reinforcement", "Training cost of production workers", and "Third party of drawing audit organization" had a minor effect on capital cost of prefabrication compared with other factors. The phenomenon occurred as those factors also had a similar effect on both the traditional on-site and prefabrication methods [58].

Table 3. Descriptive analysis of influencing factors.

\begin{tabular}{ccccc}
\hline Code & N & Mean & SD & Rank \\
\hline FD4 & 178 & 4.36 & 0.827 & 1 \\
FC1 & 178 & 4.18 & 0.871 & 2 \\
FD11 & 178 & 4.16 & 0.849 & 3 \\
FPT4 & 178 & 4.01 & 0.857 & 4 \\
FC3 & 178 & 4.00 & 0.767 & 5 \\
FPT3 & 178 & 3.99 & 0.883 & 6 \\
FD2 & 178 & 3.98 & 0.766 & 7 \\
FD9 & 178 & 3.98 & 0.809 & 8 \\
FD13 & 178 & 3.97 & 0.830 & 9 \\
FD8 & 178 & 3.92 & 0.770 & 10 \\
FC2 & 178 & 3.88 & 0.702 & 11 \\
FD12 & 178 & 3.87 & 0.840 & 12 \\
FPT2 & 178 & 3.87 & 0.755 & 13 \\
\hline
\end{tabular}


Table 3. Cont.

\begin{tabular}{ccccc}
\hline Code & N & Mean & SD & Rank \\
\hline FD14 & 178 & 3.84 & 0.913 & 14 \\
FPT12 & 178 & 3.83 & 0.880 & 15 \\
FD10 & 178 & 3.79 & 0.883 & 16 \\
FPT22 & 178 & 3.71 & 0.853 & 17 \\
FPT1 & 178 & 3.69 & 0.981 & 18 \\
FC6 & 178 & 3.69 & 0.934 & 19 \\
FPT16 & 178 & 3.67 & 0.899 & 20 \\
FD1 & 178 & 3.62 & 1.120 & 21 \\
FPT7 & 178 & 3.61 & 0.790 & 22 \\
FPT13 & 178 & 3.60 & 0.860 & 23 \\
FD5 & 178 & 3.57 & 0.888 & 24 \\
FD3 & 178 & 3.57 & 0.996 & 25 \\
FPT8 & 178 & 3.56 & 0.938 & 26 \\
FD6 & 178 & 3.49 & 0.891 & 27 \\
FC8 & 178 & 3.49 & 0.811 & 28 \\
FPT14 & 178 & 3.48 & 0.903 & 29 \\
FC7 & 178 & 3.45 & 0.902 & 30 \\
FC9 & 178 & 3.44 & 0.901 & 31 \\
FD7 & 178 & 3.42 & 0.937 & 32 \\
FC4 & 178 & 3.42 & 1.006 & 33 \\
FPT20 & 178 & 3.35 & 0.928 & 34 \\
FPT15 & 178 & 3.34 & 0.962 & 35 \\
FPT21 & 178 & 3.30 & 0.882 & 36 \\
FPT19 & 178 & 3.26 & 0.844 & 37 \\
FD15 & 178 & 3.22 & 0.911 & 38 \\
FPT6 & 178 & 3.21 & 0.895 & 39 \\
FC10 & 178 & 3.21 & 0.920 & 40 \\
FPT11 & 178 & 3.19 & 0.937 & 41 \\
FPT23 & 178 & 3.16 & 0.961 & 42 \\
FPT17 & 178 & 3.13 & 0.904 & 43 \\
FPT5 & 178 & 3.12 & 0.972 & 44 \\
FC5 & 178 & 3.12 & 0.807 & 45 \\
FPT10 & 178 & 3.10 & 0.927 & 46 \\
FPT9 & 178 & 3.09 & 0.970 & 47 \\
FPT18 & 178 & 3.09 & 0.982 & 48 \\
FD16 & 178 & 3.02 & 1.104 & 49 \\
\hline & & & & \\
\hline & 178 & & \\
\hline
\end{tabular}

\section{1. $t$-Test}

The independent sample $t$-test has been commonly used to examine whether the mean values of a specific variable from two independent groups were significantly different $[16,52,59]$. Table 4 suggests that there exists deviation between experienced and inexperienced respondents (Figure 3). For the experienced ones, "Specification and standards for prefabricated building design", "Related experience of manager", "Capacity of production line in PC", "Rationality of PC split", "Order quantity of PC", "Coordination of connection nodes of PC components", "Coordination between designer and PC manufacturer", "Operant level on installation personnel", "Node coordination between PC and on component", and "Reuse rate of PC mold" were the important factors. The experienced practitioners tended to pay more attention to the practical problems in the construction process [60], such as specification and standards guidance for design, production and installment, capacity of production line, PC split and technical connection nodes. However, as for inexperienced practitioners, "Specification and standards for prefabricated building design", "Collaborative capacity among professional designers", "Specification and standards for PC production", "Coordination between designer and client", "Related experience of designer", "Design level of teamwork", "Rationality of PC split", "Design plan for PC production line", "Operant level on installation personnel", and "Technical 
standards system of prefabricated building" were the important factors. Inexperienced respondents highlighted the regulations, potential risks and expenses. Different from the experienced group, the inexperienced respondents took "lack of professional personnel" and "training cost" into account when they decided whether to choose the prefabrication method or not [15]. Using Factor Analysis, the survey found that deviation between two series were from some factors (Figure 4), including FD1, FD7, FD8, FD10, FD15, FPT1, FPT2, FPT3, FPT4, FPT7, FPT8, FPT16, FPT18, FPT22, FC1, FC4, and FC6. Those factors were divided into two parts: practical and potential factors. The experienced respondents placed emphasis on practical problems in the production and installation process. However, the inexperienced ones pay more attention to the potential risk and expenses [61], such as training cost of professional personnel [44], procurement costs of machine [35], etc.

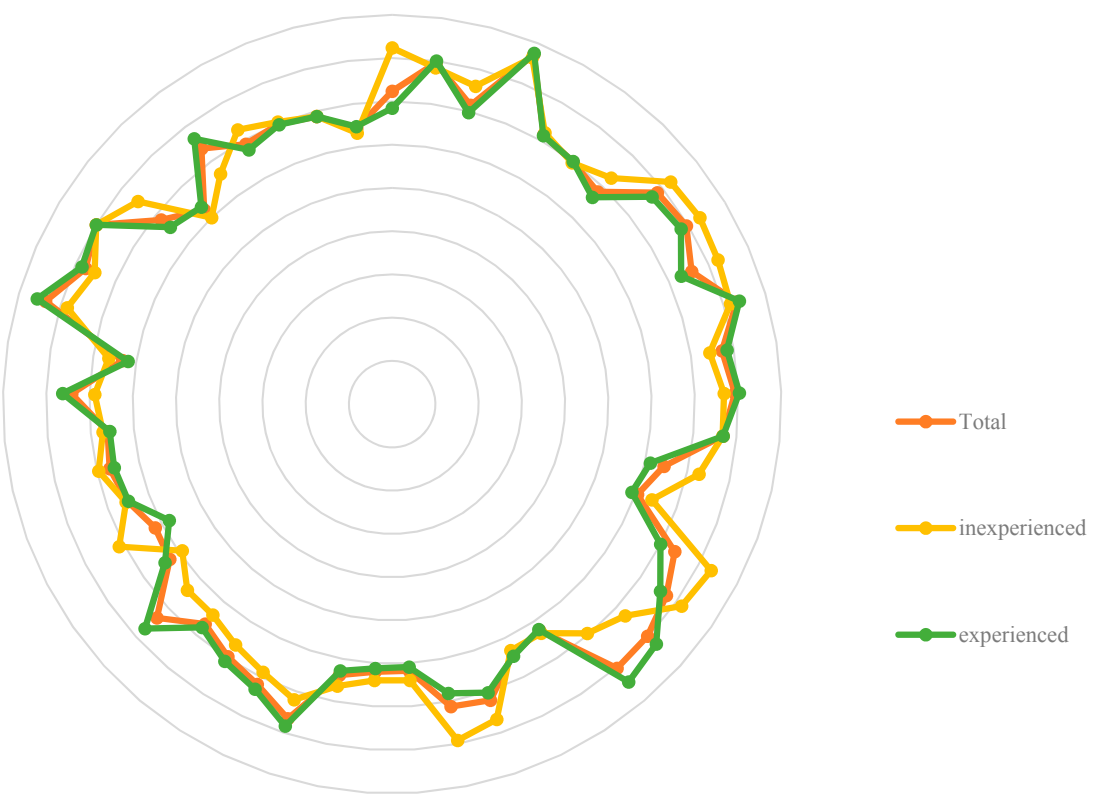

Figure 3. Factor analysis between the experienced and inexperienced respondents.

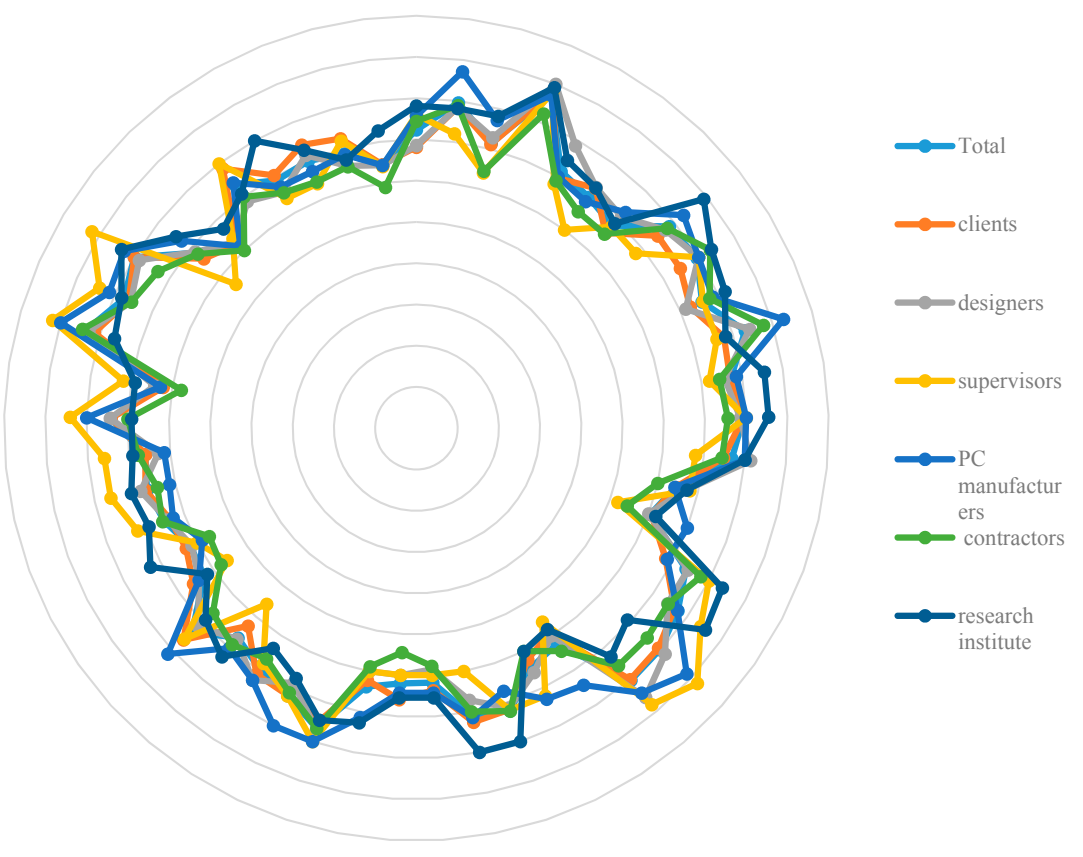

Figure 4. Factor analysis among stakeholders. 
Table 4. Independent Samples $t$-test.

\begin{tabular}{|c|c|c|c|c|c|c|c|c|}
\hline \multirow[t]{2}{*}{ Code } & \multicolumn{2}{|c|}{$\begin{array}{c}\text { Levene's Test for } \\
\text { Equality of Variances }\end{array}$} & \multicolumn{3}{|c|}{ Mean Value } & \multicolumn{2}{|c|}{$\begin{array}{c}t \text {-Test for Equality } \\
\text { of Means }\end{array}$} & \multirow{2}{*}{$\begin{array}{c}\text { Significant } \\
\text { Difference (N/Y) }\end{array}$} \\
\hline & $F$ & Sig. & Total & Series $1(\mathrm{~N})$ & Series $2(\mathrm{Y})$ & $t$ & Sig. & \\
\hline FD1 & 12.286 & 0.001 & 3.618 & 4.120 & 3.422 & 4.372 & 0.000 & $\mathrm{Y}$ \\
\hline FD2 & 5.959 & 0.016 & 3.978 & 3.920 & 4.000 & -0.584 & 0.561 & $\mathrm{~N}$ \\
\hline FD3 & 0.221 & 0.639 & 3.573 & 3.800 & 3.484 & 1.915 & 0.057 & $\mathrm{~N}$ \\
\hline FD4 & 0.299 & 0.585 & 4.360 & 4.320 & 4.375 & -0.398 & 0.691 & $\mathrm{~N}$ \\
\hline FD5 & 0.537 & 0.465 & 3.573 & 3.600 & 3.563 & 0.253 & 0.801 & $\mathrm{~N}$ \\
\hline FD6 & 1.202 & 0.275 & 3.494 & 3.480 & 3.500 & -0.134 & 0.893 & $\mathrm{~N}$ \\
\hline FD7 & 0.044 & 0.834 & 3.416 & 3.640 & 3.328 & 2.014 & 0.046 & Y \\
\hline FD8 & 0.108 & 0.743 & 3.921 & 4.120 & 3.844 & 2.174 & 0.031 & $\mathrm{Y}$ \\
\hline FD9 & 1.229 & 0.269 & 3.978 & 4.160 & 3.906 & 1.894 & 0.060 & $\mathrm{~N}$ \\
\hline FD10 & 10.341 & 0.002 & 3.787 & 4.120 & 3.656 & 3.581 & 0.001 & $\mathrm{Y}$ \\
\hline FD11 & 0.308 & 0.579 & 4.157 & 4.080 & 4.188 & -0.758 & 0.449 & $\mathrm{~N}$ \\
\hline FD12 & 5.178 & 0.024 & 3.865 & 3.720 & 3.922 & -1.278 & 0.205 & $\mathrm{~N}$ \\
\hline FD13 & 24.145 & 0.000 & 3.966 & 3.840 & 4.016 & -1.005 & 0.319 & $\mathrm{~N}$ \\
\hline FD14 & 4.508 & 0.035 & 3.843 & 3.840 & 3.844 & -0.022 & 0.982 & $\mathrm{~N}$ \\
\hline FD15 & 4.306 & 0.039 & 3.225 & 3.640 & 3.063 & 3.776 & 0.000 & $\mathrm{Y}$ \\
\hline FD16 & 6.100 & 0.014 & 3.022 & 3.200 & 2.953 & 1.201 & 0.234 & $\mathrm{~N}$ \\
\hline FPT1 & 1.398 & 0.239 & 3.685 & 4.160 & 3.500 & 4.221 & 0.000 & $\mathrm{Y}$ \\
\hline FPT2 & 0.551 & 0.459 & 3.865 & 4.080 & 3.781 & 2.406 & 0.017 & $\mathrm{Y}$ \\
\hline FPT3 & 9.215 & 0.003 & 3.989 & 3.640 & 4.125 & -3.018 & 0.004 & $\mathrm{Y}$ \\
\hline FPT4 & 10.856 & 0.001 & 4.011 & 3.480 & 4.219 & -4.957 & 0.000 & $\mathrm{Y}$ \\
\hline FPT5 & 12.510 & 0.001 & 3.124 & 3.160 & 3.109 & 0.277 & 0.783 & $\mathrm{~N}$ \\
\hline FPT6 & 0.370 & 0.544 & 3.213 & 3.160 & 3.234 & -0.497 & 0.620 & $\mathrm{~N}$ \\
\hline FPT7 & 0.167 & 0.684 & 3.607 & 3.840 & 3.516 & 2.498 & 0.013 & $\mathrm{Y}$ \\
\hline FPT8 & 3.838 & 0.052 & 3.562 & 3.960 & 3.406 & 3.661 & 0.000 & $\mathrm{Y}$ \\
\hline FPT9 & 11.054 & 0.001 & 3.090 & 3.200 & 3.047 & 0.851 & 0.398 & $\mathrm{~N}$ \\
\hline FPT10 & 15.310 & 0.000 & 3.101 & 3.200 & 3.063 & 0.758 & 0.451 & $\mathrm{~N}$ \\
\hline FPT11 & 7.259 & 0.008 & 3.191 & 3.320 & 3.141 & 1.062 & 0.291 & $\mathrm{~N}$ \\
\hline FPT12 & 17.442 & 0.000 & 3.831 & 3.600 & 3.922 & -1.988 & 0.051 & $\mathrm{~N}$ \\
\hline FPT13 & 1.047 & 0.308 & 3.596 & 3.440 & 3.656 & -1.513 & 0.132 & $\mathrm{~N}$ \\
\hline FPT14 & 2.010 & 0.158 & 3.483 & 3.320 & 3.547 & -1.511 & 0.132 & $\mathrm{~N}$ \\
\hline FPT15 & 11.349 & 0.001 & 3.337 & 3.200 & 3.391 & -1.020 & 0.312 & $\mathrm{~N}$ \\
\hline FPT16 & 5.788 & 0.017 & 3.674 & 3.200 & 3.859 & -4.214 & 0.000 & $\mathrm{Y}$ \\
\hline FPT17 & 0.020 & 0.888 & 3.135 & 2.960 & 3.203 & -1.619 & 0.107 & $\mathrm{~N}$ \\
\hline FPT18 & 9.393 & 0.003 & 3.090 & 3.560 & 2.906 & 3.834 & 0.000 & $\mathrm{Y}$ \\
\hline FPT19 & 0.917 & 0.339 & 3.258 & 3.280 & 3.250 & 0.213 & 0.832 & $\mathrm{~N}$ \\
\hline FPT20 & 0.047 & 0.828 & 3.348 & 3.480 & 3.297 & 1.185 & 0.238 & $\mathrm{~N}$ \\
\hline FPT21 & 3.038 & 0.083 & 3.303 & 3.360 & 3.281 & 0.534 & 0.594 & $\mathrm{~N}$ \\
\hline FPT22 & 3.319 & 0.070 & 3.708 & 3.440 & 3.813 & -2.663 & 0.008 & $\mathrm{Y}$ \\
\hline FPT23 & 8.282 & 0.005 & 3.157 & 3.320 & 3.094 & 1.415 & 0.159 & $\mathrm{~N}$ \\
\hline FC1 & 0.036 & 0.849 & 4.180 & 3.920 & 4.281 & -2.525 & 0.012 & $\mathrm{Y}$ \\
\hline FC2 & 8.138 & 0.005 & 3.876 & 3.760 & 3.922 & -1.249 & 0.216 & $\mathrm{~N}$ \\
\hline FC3 & 0.012 & 0.911 & 4.000 & 4.000 & 4.000 & 0.000 & 1.000 & $\mathrm{~N}$ \\
\hline FC4 & 7.616 & 0.006 & 3.416 & 3.760 & 3.281 & 2.578 & 0.012 & $\mathrm{Y}$ \\
\hline FC5 & 0.674 & 0.413 & 3.124 & 3.000 & 3.172 & -1.279 & 0.202 & $\mathrm{~N}$ \\
\hline FC6 & 10.619 & 0.001 & 3.685 & 3.320 & 3.828 & -2.967 & 0.004 & $\mathrm{Y}$ \\
\hline FC7 & 2.197 & 0.140 & 3.449 & 3.640 & 3.375 & 1.772 & 0.078 & $\mathrm{~N}$ \\
\hline FC8 & 0.038 & 0.845 & 3.494 & 3.520 & 3.484 & 0.263 & 0.793 & $\mathrm{~N}$ \\
\hline FC9 & 0.184 & 0.668 & 3.438 & 3.440 & 3.438 & 0.017 & 0.987 & $\mathrm{~N}$ \\
\hline FC10 & 7.405 & 0.007 & 3.213 & 3.160 & 3.234 & -0.443 & 0.659 & $\mathrm{~N}$ \\
\hline
\end{tabular}

\subsection{One-Way ANOVA}

One-way ANOVA has been widely used to check whether the mean values of a specific variable from more than two independent groups are significantly different [8].

\subsubsection{One-Way ANOVA for the Stakeholders}

Different in corporate responsibility of the stakeholders in the industrial chain, the stakeholders tend to adopt different tactics of cost management (Table 5). The clients control the capital cost from the perspective of the whole construction chain [62], including design, production, transport and installation. "Specification and standards for prefabricated building design", "Related experience of manager", "Capacity of production line in PC", "Operant level on installation personnel", "Coordination of connection nodes of PC components", "Order quantity of PC", "Coordination between designer and PC manufacturer", "Mechanical efficiency of tower crane", "Rationality of PC split", 
and "Node coordination between PC and on-site component". As a sponsor and investor, the clients suggest that the cost management should be process-oriented, including design, production, transport, and on-site installation. For designers, "Specification and standards for prefabricated building design", "Capacity of production line in PC", "Rationality of PC split", "Related experience of manager", "Reuse ratio of standard components", "Order quantity of PC", "Collaborative capacity among professional designers", "Coordination between designer and PC manufacturer", "Standard component catalogue of prefabricated building", and "Coordination of connection nodes of PC components" can influence cost management. The designers recognize the factors related to the design stage as the priority, such as specification, standards and coordination. Using traditional design methods, the designers seek guidance for design, such as specification and standards for prefabrication design, standard components and standard component catalogue [5]. The designers believed that experience and knowledge of designers had effect on cost management and that standardized design can reduce the cost of PC. Meanwhile, the designers stressed that design quality can affect the production of PC. For the supervisors, "Related experience of manager", "Order quantity of PC", "Operant level on installation personnel", "Specification and standards for prefabricated building design", "Capacity of production line in PC", "Coordination of all types of work on site", "Design plan for PC production line", "Transport distance", "Collaborative capacity among professional designers", and "Coordination of connection nodes of PC components" were the most important factors. The supervisors pay attention to production, transport, and installation process. "Materials supplied by client" has been the most common procurement mode [48]. As the representative of the clients, the supervisors are involved in the production and installation process. The supervisors pay more attention to the production of PC at a factory and on-site installment. They believed that successful on-site project management and mass production were a primary way to reduce the capital cost of prefabrication [40]. For the PC manufacturers, "Rationality of PC split", "Related experience of manager", "Order quantity of PC", "Specification and standards for prefabricated building design", "Coordination between designer and PC manufacturer", "Capacity of production line in PC", "Operant level on installation personnel”, "Related experience of designer", "Coordination of all types of work on site", and "Efficiency of production worker" were important factors. Compared with the traditional materials supplier, the PC manufacturers take actively apart in the design, production, transportation and installation stages. The PC manufacturers found that the design frozen early and rationality of PC split had a positive effect on the cost of mold which make up a large proportion of the PC cost [40]. PC manufacturers reported that coordination among stakeholders can reduce capital cost. The PC manufacturers focused on cooperation with the designers, and suggested that mass production can contribute positively to cost management. As for on-site contractors, "Rationality of PC split", "Related experience of manager", "Collaborative capacity among professional designers", "Specification and standards for prefabricated building design", "Coordination between designer and PC manufacturer", "Related experience of designer", "Design level of teamwork", "Specification and standards for PC production", "Reuse rate of PC mold", and "Order quantity of PC" were significant factors. The contractors stressed on the factors mainly related to the installation on-site. Using "Materials supplied by client", the contractors ignored the $\mathrm{Cp}$, thus paying more attention to $\mathrm{Ci}$. The contractors suggested that the quality of design and install on-site, suitability for component connection, and mass production can reduce the capital cost of prefabrication $[11,23]$. From the perspective of research institutes, "Specification and standards for prefabricated building design", "Related experience of designer", "Coordination of connection nodes of PC components", "Node coordination between PC and on-site component", "Design plan for PC production line", "Collaborative capacity among professional designers", "Specification and standards for PC production", "Operant level on installation personnel", "Design level of teamwork", and "Reuse ratio of standard components" were the primary factors. The researchers highlighted the importance of instruction norms and technological innovation. The researchers suggested that specification, standards and technology had positive effect on the cost management of prefabrication. 
Table 5. ANOVA for different stakeholders.

\begin{tabular}{|c|c|c|c|c|c|c|c|c|c|c|c|c|}
\hline \multirow{2}{*}{ Code } & \multicolumn{2}{|c|}{ Test of Homogeneity of Variances } & \multicolumn{7}{|c|}{ Mean Value } & \multicolumn{2}{|c|}{ One-Way-Test for Equality of Means } & \multirow{2}{*}{$\begin{array}{c}\text { Significant } \\
\text { Difference (N/Y } \\
\end{array}$} \\
\hline & Levene Statistic & Sig. & Total & Series 1 & Series 2 & Series 3 & Series 4 & Series 5 & Series 6 & $\mathbf{F}$ & Sig. & \\
\hline FD1 & 0.718 & 0.610 & 3.618 & 3.407 & 3.429 & 3.800 & 3.786 & 3.722 & 3.909 & 1.083 & 0.372 & $\mathrm{~N}$ \\
\hline FD2 & 0.636 & 0.673 & 3.978 & 3.926 & 3.929 & 3.600 & 4.357 & 3.944 & 3.909 & 2.039 & 0.076 & $\mathrm{~N}$ \\
\hline FD3 & 1.826 & 0.110 & 3.573 & 3.556 & 3.643 & 3.200 & 3.857 & 3.222 & 3.909 & 2.237 & 0.053 & $\mathrm{~N}$ \\
\hline FD4 & 0.732 & 0.601 & 4.360 & 4.407 & 4.500 & 4.400 & 4.357 & 4.111 & 4.455 & 0.908 & 0.477 & $\mathrm{~N}$ \\
\hline FD5 & 7.454 & 0.000 & 3.573 & 3.481 & 3.929 & 3.400 & 3.500 & 3.444 & 3.727 & 1.427 & 0.217 & $\mathrm{~N}$ \\
\hline FD6 & 1.258 & 0.284 & 3.494 & 3.630 & 3.643 & 3.000 & 3.429 & 3.278 & 3.636 & 1.616 & 0.158 & $\mathrm{~N}$ \\
\hline FD7 & 2.756 & 0.020 & 3.416 & 3.296 & 3.571 & 3.400 & 3.643 & 3.278 & 3.455 & 0.820 & 0.537 & $\mathrm{~N}$ \\
\hline FD8 & 0.578 & 0.717 & 3.921 & 3.741 & 3.857 & 3.400 & 4.143 & 3.889 & 4.455 & 4.553 & 0.001 & $\mathrm{Y}$ \\
\hline FD9 & 1.440 & 0.212 & 3.978 & 3.741 & 4.000 & 4.000 & 4.000 & 4.167 & 4.182 & 1.638 & 0.153 & $\mathrm{~N}$ \\
\hline FD10 & 2.629 & 0.026 & 3.787 & 3.630 & 3.571 & 3.800 & 3.929 & 3.889 & 4.091 & 1.458 & 0.206 & $\mathrm{~N}$ \\
\hline FD11 & 1.586 & 0.166 & 4.157 & 3.889 & 4.214 & 3.800 & 4.643 & 4.389 & 3.909 & 4.633 & 0.001 & Y \\
\hline FD12 & 2.051 & 0.074 & 3.865 & 3.852 & 3.786 & 3.600 & 3.929 & 3.722 & 4.273 & 1.554 & 0.176 & $\mathrm{~N}$ \\
\hline FD13 & 9.571 & 0.000 & 3.966 & 3.963 & 3.929 & 4.000 & 4.000 & 3.778 & 4.273 & 0.996 & 0.422 & $\mathrm{~N}$ \\
\hline FD14 & 6.249 & 0.000 & 3.843 & 3.741 & 4.071 & 3.400 & 4.000 & 3.722 & 4.000 & 1.393 & 0.229 & $\mathrm{~N}$ \\
\hline FD15 & 0.633 & 0.675 & 3.225 & 3.222 & 3.357 & 3.400 & 3.214 & 3.000 & 3.364 & 0.727 & 0.604 & $\mathrm{~N}$ \\
\hline FD16 & 0.580 & 0.715 & 3.022 & 3.037 & 3.000 & 2.600 & 3.500 & 2.722 & 3.091 & 1.943 & 0.090 & $\mathrm{~N}$ \\
\hline FPT1 & 1.625 & 0.156 & 3.685 & 3.407 & 3.714 & 4.000 & 3.429 & 3.889 & 4.182 & 3.067 & 0.011 & $\mathrm{Y}$ \\
\hline FPT2 & 3.396 & 0.006 & 3.865 & 3.815 & 3.714 & 4.200 & 3.857 & 3.722 & 4.273 & 2.289 & 0.048 & $\mathrm{Y}$ \\
\hline FPT3 & 2.751 & 0.020 & 3.989 & 3.963 & 4.071 & 4.600 & 4.429 & 3.778 & 3.455 & 4.919 & 0.000 & $\mathrm{Y}$ \\
\hline FPT4 & 3.409 & 0.006 & 4.011 & 4.000 & 4.286 & 4.400 & 4.214 & 3.778 & 3.636 & 2.816 & 0.018 & $\mathrm{Y}$ \\
\hline FPT5 & 5.120 & 0.000 & 3.124 & 2.963 & 3.000 & 2.800 & 3.714 & 3.222 & 2.909 & 3.142 & 0.010 & $Y$ \\
\hline FPT6 & 0.786 & 0.561 & 3.213 & 3.111 & 3.286 & 3.600 & 3.643 & 3.000 & 3.000 & 2.611 & 0.026 & $\mathrm{Y}$ \\
\hline FPT7 & 2.878 & 0.016 & 3.607 & 3.593 & 3.571 & 3.600 & 3.357 & 3.611 & 4.000 & 1.697 & 0.138 & $\mathrm{~N}$ \\
\hline FPT8 & 2.188 & 0.058 & 3.562 & 3.630 & 3.357 & 3.000 & 3.571 & 3.500 & 4.000 & 2.094 & 0.068 & $\mathrm{~N}$ \\
\hline FPT9 & 4.220 & 0.001 & 3.090 & 3.185 & 2.929 & 3.000 & 3.214 & 2.889 & 3.273 & 0.830 & 0.530 & $\mathrm{~N}$ \\
\hline FPT10 & 3.879 & 0.002 & 3.101 & 3.296 & 3.000 & 3.000 & 3.214 & 2.722 & 3.273 & 2.066 & 0.072 & $\mathrm{~N}$ \\
\hline FPT11 & 3.450 & 0.005 & 3.191 & 3.111 & 3.000 & 3.000 & 3.571 & 2.944 & 3.636 & 2.964 & 0.014 & $\mathrm{Y}$ \\
\hline FPT12 & 3.890 & 0.002 & 3.831 & 3.741 & 3.857 & 4.000 & 4.000 & 3.833 & 3.727 & 0.453 & 0.810 & $\mathrm{~N}$ \\
\hline FPT13 & 2.213 & 0.055 & 3.596 & 3.593 & 3.429 & 3.600 & 4.000 & 3.556 & 3.364 & 1.828 & 0.110 & $\mathrm{~N}$ \\
\hline FPT14 & 1.275 & 0.277 & 3.483 & 3.556 & 3.643 & 3.400 & 3.643 & 3.333 & 3.182 & 1.128 & 0.347 & $\mathrm{~N}$ \\
\hline FPT15 & 1.628 & 0.155 & 3.337 & 3.148 & 3.357 & 2.800 & 3.500 & 3.444 & 3.636 & 1.756 & 0.125 & $\mathrm{~N}$ \\
\hline FPT16 & 5.227 & 0.000 & 3.674 & 3.815 & 3.571 & 3.800 & 4.071 & 3.333 & 3.455 & 2.916 & 0.015 & Y \\
\hline FPT17 & 0.877 & 0.498 & 3.135 & 3.296 & 3.214 & 2.800 & 3.214 & 2.889 & 3.091 & 1.257 & 0.285 & $\mathrm{~N}$ \\
\hline FPT18 & 1.871 & 0.102 & 3.090 & 3.148 & 3.071 & 3.000 & 2.929 & 2.833 & 3.636 & 2.129 & 0.064 & $\mathrm{~N}$ \\
\hline FPT19 & 2.815 & 0.018 & 3.258 & 3.185 & 3.214 & 3.600 & 3.143 & 3.278 & 3.455 & 0.765 & 0.576 & $\mathrm{~N}$ \\
\hline FPT20 & 4.319 & 0.001 & 3.348 & 3.370 & 3.429 & 3.800 & 3.071 & 3.222 & 3.545 & 1.366 & 0.239 & $\mathrm{~N}$ \\
\hline FPT21 & 3.001 & 0.013 & 3.303 & 3.296 & 3.143 & 3.800 & 3.071 & 3.389 & 3.455 & 1.422 & 0.219 & $\mathrm{~N}$ \\
\hline FPT22 & 4.196 & 0.001 & 3.708 & 3.704 & 3.714 & 4.200 & 4.000 & 3.500 & 3.455 & 2.212 & 0.055 & $\mathrm{~N}$ \\
\hline FPT23 & 2.132 & 0.064 & 3.157 & 3.111 & 3.214 & 3.600 & 3.143 & 2.889 & 3.455 & 1.471 & 0.202 & $\mathrm{~N}$ \\
\hline
\end{tabular}


Table 5. Cont

\begin{tabular}{|c|c|c|c|c|c|c|c|c|c|c|c|c|}
\hline \multirow{2}{*}{ Code } & \multicolumn{2}{|c|}{ Test of Homogeneity of Variances } & \multicolumn{7}{|c|}{ Mean Value } & \multicolumn{2}{|c|}{ One-Way-Test for Equality of Means } & \multirow{2}{*}{$\begin{array}{c}\text { Significant } \\
\text { Difference (N/Y) }\end{array}$} \\
\hline & Levene Statistic & Sig. & Total & Series 1 & Series 2 & Series 3 & Series 4 & Series 5 & Series 6 & F & Sig. & \\
\hline $\mathrm{FC} 1$ & 1.242 & 0.291 & 4.180 & 4.074 & 4.143 & 4.600 & 4.500 & 4.222 & 3.818 & 2.244 & 0.052 & $\mathrm{~N}$ \\
\hline FC2 & 2.397 & 0.039 & 3.876 & 3.815 & 3.786 & 4.200 & 4.071 & 3.778 & 3.909 & 1.191 & 0.316 & $\mathrm{~N}$ \\
\hline FC3 & 2.519 & 0.031 & 4.000 & 4.000 & 3.929 & 4.600 & 4.143 & 3.667 & 4.182 & 3.275 & 0.008 & Y \\
\hline FC4 & 0.972 & 0.436 & 3.416 & 3.296 & 3.429 & 2.800 & 3.643 & 3.389 & 3.727 & 1.643 & 0.151 & $\mathrm{~N}$ \\
\hline FC5 & 2.341 & 0.044 & 3.124 & 3.111 & 3.143 & 3.200 & 3.071 & 3.000 & 3.364 & 0.598 & 0.701 & $\mathrm{~N}$ \\
\hline FC6 & 1.831 & 0.109 & 3.685 & 3.926 & 3.429 & 4.000 & 3.714 & 3.500 & 3.545 & 1.794 & 0.116 & $\mathrm{~N}$ \\
\hline FC7 & 0.433 & 0.825 & 3.449 & 3.519 & 3.286 & 3.200 & 3.357 & 3.278 & 4.000 & 2.456 & 0.035 & Y \\
\hline FC8 & 0.282 & 0.922 & 3.494 & 3.704 & 3.571 & 3.200 & 3.357 & 3.222 & 3.636 & 2.211 & 0.055 & $\mathrm{~N}$ \\
\hline FC9 & 1.816 & 0.112 & 3.438 & 3.630 & 3.286 & 3.600 & 3.429 & 3.278 & 3.364 & 0.970 & 0.438 & $\mathrm{~N}$ \\
\hline FC10 & 0.942 & 0.456 & 3.213 & 3.222 & 3.214 & 3.200 & 3.214 & 2.944 & 3.636 & 1.571 & 0.171 & $\mathrm{~N}$ \\
\hline
\end{tabular}

maximum and the minimum variance is less than 3.0 , then the variance is recognized as homogeneous. 
Stakeholders held different opinions on FD8, FD11, FPT1, FPT2, FPT3, FPT4, PFT5, FPT6, FPT11, FPT16, FC3 and FC7. Those factors can be divided into three parts: design related, production related, and on-site installment related. The result revealed that stakeholders tended to seek their own interests. The clients as the project initiator focused on the whole construction process, while the contractors emphasized the on-site process. Designers focused on the design process and PC manufacturers paid more attention to the production of PC.

\subsubsection{One-Way ANOVA Test for the Function}

Different in function, top managers (Group 1), middle managers (Group 2), first-line managers (Group 3) and technicians (Group 4) held different opinions on cost management (Table 6). Top managers owned actual project management experience and holistic ideas. "Specification and standards for prefabricated building design", "Capacity of production line in PC", "Related experience of manager", "Order quantity of PC", "Efficiency of production worker," "Collaborative capacity among professional designers", "Coordination between designer and PC manufacture", "Node coordination between PC and on-site component", "Transport distance", and "Coordination of all types of work on site" were the main factors affecting the cost of prefabrication. Those factors were divided into technology and management parts related to the whole industry chain. The top managers suggested that the feasibility of technology and the professional qualities of the participants had impact on cost management [21]. Moreover, the cooperation, consciousness and subjective initiative can affect cost management as well. Middle managers cared more about the practical factors in the view of the stakeholders. "Specification and standards for prefabricated building design", "Rationality of PC split", "Related experience of manager", "Order quantity of PC", "Collaborative capacity among professional designers", "Reuse ratio of standard components", "Capacity of production line in PC", "Coordination between designer and PC manufacturer", "Reuse rate of PC mold", and "Operant level on installation personnel" were the important factors for them. The middle managers suggested that rationality of management, experience of managers, and coordination between stakeholders influenced the cost management of prefabrication. First-line managers were personally involved in the prefabrication project, and paid more attention to the practical problems, which included "Node coordination between PC and on-site component", "Production technology of PC", "Diversity of prefabricated building structure", "Technical standards system of prefabricated building", "Specification and Standards for prefabricated building design", "Collaborative capacity among professional designers", "Operant level on installation personnel", "Coordination of connection nodes of PC components", "Specification and standards for PC production", and "Technical specifications and standards for PC installation". The survey reported that first-line managers highlighted technical innovation, standards and specifications to guide production, design and installation, and rationality of project management. Technicians as technical staff, like technologist, surveyor, designer etc., emphasized the factors related to technology, including "Specification and standards for prefabricated building design", "Rationality of PC split", "Coordination of connection nodes of PC components", "Related experience of manager", "Operant level on installation personnel", "Coordination between designer and PC manufacturer", "Related experience of designer", "Order quantity of PC", "Capacity of production line in PC", and "Node coordination between PC and on-site component". Those factors can help facilitate design, installment and production, and are technical problems involved in node connection and installation.

The results revealed that respondents had a cognitive bias on the factors (Figure 5.), which was mainly distributed in design, production and transportation stages. Based on the respective cognition, interests and function, participants provided different judgments (Table 7). 
Table 6. Variance Analysis for different function.

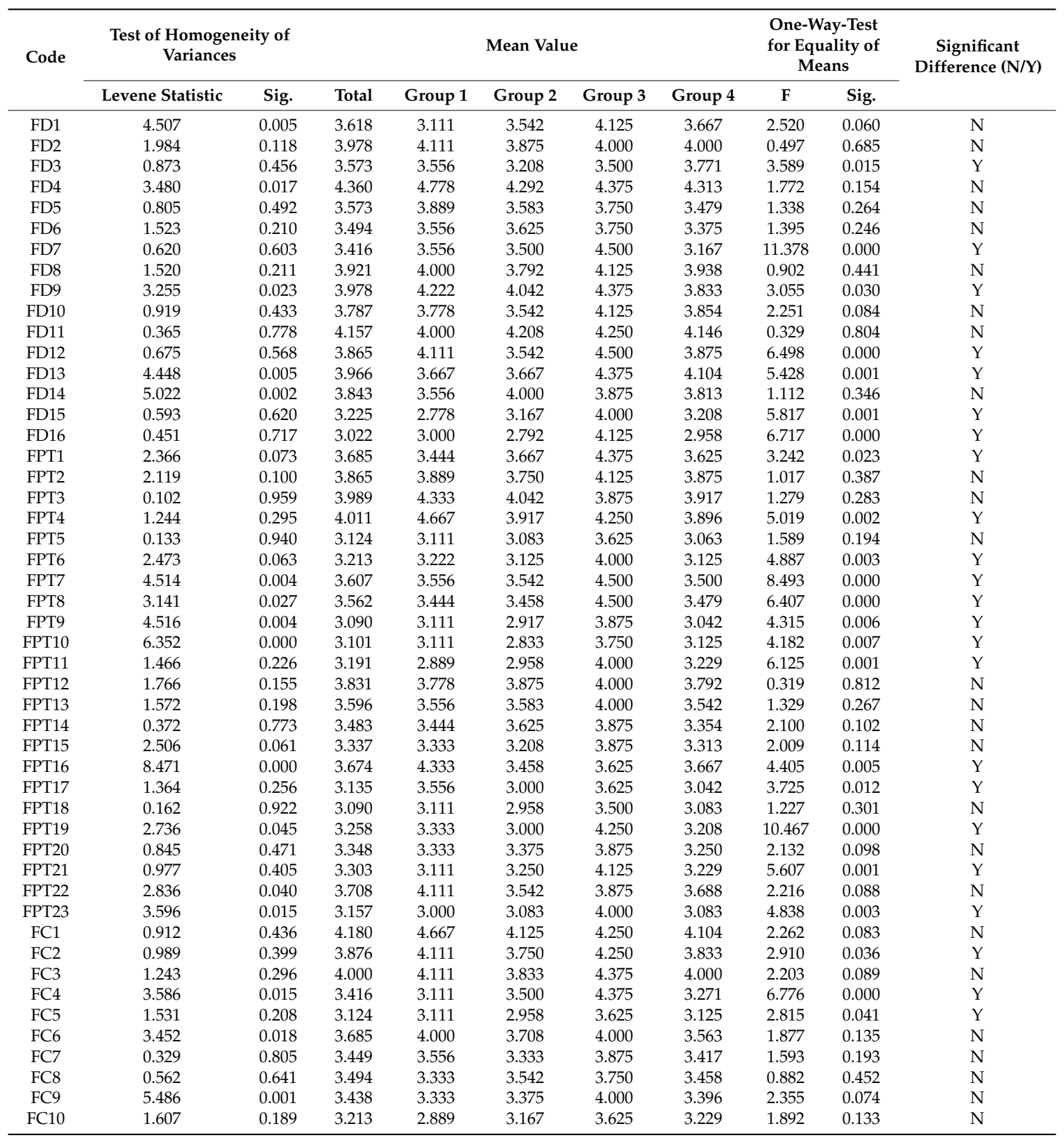

Notes: For FD1, FD4, FD9, FD13, FD14, FPT7, FPT8, FPT9, FPT10, FPT16, FPT19, FPT22, FPT23, FC4, FC6, FC9, sig. < 0.05; if the ratio of the maximum and the minimum variance is less than 3.0 , then the variance is recognized as homogeneous.

Table 7. Functional deviation of different participants.

\begin{tabular}{ccl}
\hline Function & Context & Content \\
\hline top manager & industry chain & $\begin{array}{l}\text { technology, management, cooperation of team exterior and team } \\
\text { inner, consciousness and human subjective initiative }\end{array}$ \\
\hline middle manager & enterprise & $\begin{array}{l}\text { technology, management, cooperation of team exterior and team } \\
\text { inner, consciousness }\end{array}$ \\
\hline first-line manager & project & technology, management on-site, cooperation within a team \\
\hline technician & practical problem & technology, cooperation of teamwork, and practical problems \\
\hline
\end{tabular}




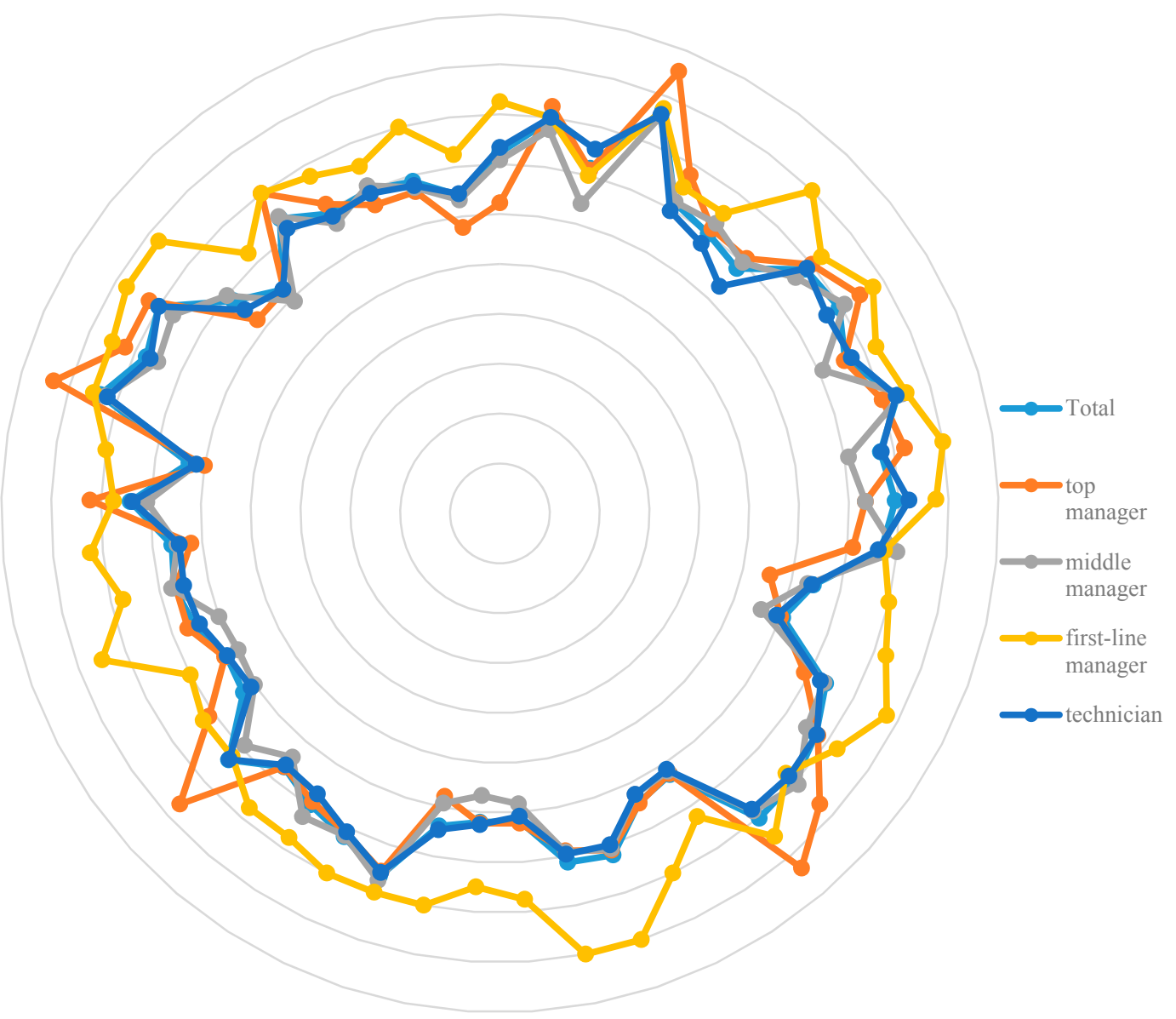

Figure 5. Factor analysis among different function.

\section{Discussion}

The survey explored the factors affecting the capital cost of prefabrication and compared them between different groups of respondents [63]. The interpretation of the survey outcomes, and consequent discussions are based on the results from the statistical analyses. To ensure the effectiveness of this study, the results were presented to three experts experienced in prefabrication for validation, including one policy maker and two project managers. The study recognized some general trends and revealed some specific attitudes about the surveyed respondents. The survey implied that precast ratio of $30 \%$ received the highest proportion $(31.3 \%)$. This result revealed that the government policy had a significant effect on promoting prefabrication development [64]. The precast ratio of steel structure systems $(80 \%)$ was higher than reinforced concrete systems (30\%). This result suggested that steel was easier to be prefabricated than concrete component [16]. Precast staircase (90.5\%), precast facades $(85.7 \%)$ and semi-precast slab $(69.0 \%)$ were the most popular PC in prefabrication. Residential housing $(81 \%)$ became a common pilot project for promoting the prefabrication, especially in indemnificatory housing and affordable housing.

Some of the 49 factors in the survey were significant within the total sample. "Specification and standards for prefabricated building design", "Related experience of manager", "Rationality of PC split", "Capacity of production line in PC", "Operant level on installation personnel", "Order quantity of PC", "Coordination between designer and PC manufacturer", "Collaborative capacity among professional designers", "Coordination of connection nodes of PC components", and "Related experience of designer" were the most important factors among the 49 factors. Those factors reflect norms and standards, management mode, scale economy, etc. Meanwhile, those factors cover the design, production and transport, and installation stages; thus, a process-oriented and diversified 
management mode can be applied for cost management. However, "Attrition rate of reinforcement", "Training cost of production workers", and "Third party of drawing audit organization" were also worth attention. Those cost factors also occur in traditional on-site construction. Furthermore, prefabrication was still in the early stage and supporting systems were not perfect. The stakeholders paid more attention to the significant cost increment, and were easy to overlook auxiliary factors.

Experience as a variable had an impact on the promotion of prefabrication. The experienced practitioners paid more attention to the practical factors in design, production [62], transport, and installation processes. However, the inexperienced ones took the potential risks and expenses into account when they chose the prefabrication [1]. For the experienced ones, the government can take measures to solve practical problems, such as technical innovation and management mode. For the inexperienced ones, the government can formulate preferential policies to increase stakeholder interest or formulate mandatory policies to force stakeholders.

Corporate responsibility has an effect on the promotion of prefabrication. The clients play a dominant role in promoting prefabrication. The clients are the decision-maker who determine whether to adopt the prefabrication mode or not. As the leader of the industry chain, the clients focus on the whole process and all the elements when they control cost of prefabrication [22]. However, the designer, PC manufacturers, and the contractors are concerned more about their own interests. Therefore, the policy makers can take advantage of the dominant role of clients, who are similar to "bellwether" among stakeholders, enhance the enthusiasm of clients, and increase the participation of other stakeholders, e.g., designers, supervisors, PC manufacturers, and contractors in prefabrication construction chain.

Participant function can affect the cost management of prefabrication. There was cognitive bias of cost management among the participants of different function. The top managers indicated that enhancing the cooperation [65], improving the management and enhancing the initiative can improve the efficiency and reduce the capital cost in the industry chain [33]. Middle managers focused on practical factors that were closely associated with their own interests. First-line managers were directly related to the prefabrication, and paid more attention to the practical problems in prefabrication project management. Nevertheless, technicians stated that improving the management skills and solving practical technical problems can be beneficial in terms of the reduction in the physical consumption and capital cost [35].

\section{Conclusions}

The higher capital cost is the most significant barrier to the development of prefabrication $[7,39]$. This study explored the factors affecting the capital cost of prefabrication in comparison with the traditional on-site construction. "Specification and standards for prefabricated building design", "Related experience of manager", "Rationality of PC split", "Capacity of production line in PC", "Operant level on installation personnel", "Order quantity of PC", "Coordination between designer and PC manufacturer", "Collaborative capacity among professional designers", "Coordination of connection nodes of PC components", and "Related experience of designer" were the most important factors. The survey reported that "Specification and standards for prefabricated building design" was the most important factor for cost management [5]. Thus, the government and the professional association can formulate standards and specifications to promote the prefabrication development.

Experience in prefabrication project management has positive impact on cost management. The government can extend prefabrication in public projects, such as affordable housing projects, economic and functional houses and infrastructure projects. The managers can generalize the management and technical experience of the pilot projects to large-scaled prefabricated projects [21].

Innovation of management and technology are conducive to promoting prefabrication [66]. The results suggested that collaborative management enabled stakeholders to be integrated into a "Big Network" to strengthen cooperation [67], and that cooperation had a positive effect on the cost management [23]. The EPC (Engineering Procurement Construction) contracting mode is suitable 
for prefabrication. Based on information exchange, resource sharing, and interest integration, the stakeholders can improve management performance and technological innovation [68].

The clients as the initiators of the projects play an important role in cost management [63]. A reasonable contracting mode is necessary for cost management. Thus, the clients can control capital cost from the perspective of the whole construction chain, and strengthen the communication and cooperation among the stakeholders, such as the designers, supervisors, PC manufactures, and contractors. Furthermore, professional training for prefabrication should be provided for different function of staff, which can eliminate cognitive bias of cost management and enhance consciousness of prefabrication.

Due to the research context, the empirical analysis was based on a relatively small sample from China engineering projects. The internal relations among 49 cost factors were not explored. Moreover, influence of other fixed factors such as location, project size, enterprises affiliation were not examined, which was the key limitation of this study. Nonetheless, this study provides practitioners and decision makers with valuable references to make policies and measures for prefabrication cost management. Although the study was performed in the context of China, the research questions were based on international literature reviews. Additionally, the results of our study agreed with previous relevant studies. Thus, the consequent results can be generalized. In further study, the synergistic effect for cost management would be analyzed, and the new management mode suitable for prefabrication would be explored. This study contributes to the literature relating to cost management in prefabrication and the findings can provide an understanding of the implementation of prefabrication.

Acknowledgments: This research was partly supported by Project of the National Thirteenth Five-Year Research Program of China (2016YFC0701606). The authors are grateful to people who helped undertake the research and improve this article. We would also like to thank the editors and reviewers of Sustainability for their insightful comments on this research.

Author Contributions: This paper was developed as part of Hong Xue's Ph.D. research, which provided the originality. While Hong Xue conceived and wrote the paper. As her Ph.D. supervisor, Shoujian Zhang designed research idea, secured the research grant, and supervised the research direction. Yikun Su stimulated the research idea and advised on analysis tools, research data collection and analysis. Zezhou Wu stimulated the research idea and advised on the structure, providing feedback for improving the initial draft of the paper.

Conflicts of Interest: The authors declare no conflicts of interest.

\section{References}

1. Arashpour, M.; Wakefield, R.; Lee, E.W.M.; Chan, R.; Hosseini, M.R. Analysis of interacting uncertainties in on-site and off-site activities: Implications for hybrid construction. Int. J. Proj. Manag. 2016, 34, 1393-1402. [CrossRef]

2. Matthews, J.; Love, P.E.D.; Heinemann, S.; Chandler, R.; Rumsey, C.; Olatunj, O. Real time progress management: Re-engineering processes for cloud-based BIM in construction. Autom. Constr. 2015, 58, 38-47. [CrossRef]

3. Low, S.P. Quantifying the relationships between buildability, structural quality and productivity in construction. Struct. Surv. 2001, 19, 106-112.

4. Hwang, B.; Zhao, X.; Tan, L.L.G. Green building projects: Schedule performance, influential factors and solutions. Eng. Constr. Arch. Manag. 2015, 22, 327-346. [CrossRef]

5. Jaillon, L.; Poon, C.S. Life cycle design and prefabrication in buildings: A review and case studies in Hong Kong. Autom. Const. 2014, 39, 195-202. [CrossRef]

6. Kim, M.; Woo, C.; Rho, J.; Chung, Y. Environmental Capabilities of Suppliers for Green Supply Chain Management in Construction Projects: A Case Study in Korea. Sustainability 2016, 8, 82. [CrossRef]

7. Mao, C.; Xie, F.; Hou, L.; Wu, P.; Wang, J.; Wang, X. Cost analysis for sustainable off-site construction based on a multiple-case study in China. Habitat Int. 2016, 57, 215-222. [CrossRef]

8. Gan, Y.; Shen, L.; Chen, J.; Tam, V.; Tan, Y.; Illankoon, I. Critical Factors Affecting the Quality of Industrialized Building System Projects in China. Sustainability 2017, 9, 216. [CrossRef] 
9. Faghirinejadfard, A.; Mahdiyar, A.; Marsono, A.K.; Mohandes, S.R.; Omrany, H.; Tabatabaee, S.; Tap, M.M. Economic Comparison of Industrialized Building System and Conventional Construction System Using Building Information Modeling. J. Tecnol. 2016, 78, 195-207. [CrossRef]

10. Tao, W.; Yulong, L.; Limao, Z.; Guijun, L. Case Study of Integrated Prefab Accommodations System for Migrant On-Site Construction Workers in China. J. Prof. Issue Eng. Educ. Pract. 2016, 142, 1-11.

11. Chen, Y.; Okudan, G.E.; Riley, D.R. Decision support for construction method selection in concrete buildings: Prefabrication adoption and optimization. Autom. Constr. 2010, 19, 665-675. [CrossRef]

12. Zabihi, H.; Habib, F.; Mirsaeedie, L. Definitions, concepts and new directions in Industrialized Building Systems (IBS). KSCE J. Civ. Eng. 2013, 17, 1199-1205. [CrossRef]

13. Lopez, D.; Froese, T.M. Analysis of Costs and Benefits of Panelized and Modular Prefabricated Homes. Proc. Eng. 2016, 145, 1291-1297. [CrossRef]

14. Seaden, G.; Manseau, A. Public policy and construction innovation. Build. Res. Inf. 2001, 29, $182-196$. [CrossRef]

15. Chiang, Y.; Hon-Wan Chan, E.; Ka-Leung Lok, L. Prefabrication and barriers to entry-A case study of public housing and institutional buildings in Hong Kong. Habitat Int. 2006, 30, 482-499. [CrossRef]

16. Tam, V.W.Y.; Tam, C.M.; Zeng, S.X.; Ng, W.C.Y. Towards adoption of prefabrication in construction. Build. Environ. 2007, 42, 3642-3654. [CrossRef]

17. Liu, X.C.; Pu, S.H.; Zhang, A.L.; Xu, A.X.; Ni, Z.; Sun, Y.; Ma, L. Static and seismic experiment for bolted-welded joint in modularized prefabricated steel structure. J. Constr. Steel Res. 2015, 115, 417-433. [CrossRef]

18. Isaac, S.; Bock, T.; Stoliar, Y. A methodology for the optimal modularization of building design. Autom. Constr. 2016, 65, 116-124. [CrossRef]

19. Luo, L.; Mao, C.; Shen, L.; Li, Z. Risk factors affecting practitioners' attitudes toward the implementation of an industrialized building system:A case study from China. Eng. Constr. Arch. Manag. 2015, 22, 622-643.

20. Chen, Y.; Okudan, G.E.; Riley, D.R. Sustainable performance criteria for construction method selection in concrete buildings. Autom. Constr. 2010, 19, 235-244. [CrossRef]

21. Gibb, A.; Isack, F. Re-engineering through pre-assembly: Client expectations and drivers. Build. Res. Inf. 2003, 31, 146-160. [CrossRef]

22. Pan, W.; Gibb, A.G.F.; Dainty, A.R.J. Perspectives of UK housebuilders on the use of offsite modern methods of construction. Constr. Manag. Econ. 2007, 25, 183-194. [CrossRef]

23. Tan, Y.; Shen, L.; Yao, H. Sustainable construction practice and contractors' competitiveness: A preliminary study. Habitat Int. 2011, 35, 225-230. [CrossRef]

24. Amin Hosseini, S.M.; de la Fuente, A.; Pons, O. Multi-criteria decision-making method for assessing the sustainability of post-disaster temporary housing units technologies: A case study in Bam, 2003. Sustain. Cities Soc. 2016, 20, 38-51. [CrossRef]

25. Shahzad, W.; Mbachu, J.; Domingo, N. Marginal productivity gained through prefabrication: Case studies of building projects in auckland. Buildings 2015, 5, 196-208. [CrossRef]

26. Onat, N.C.; Kucukvar, M.; Halog, A.; Cloutier, S. Systems thinking for life cycle sustainability assessment: A review of recent developments, applications, and future perspectives. Sustainability 2017, 9, 706. [CrossRef]

27. Voellinger, T.; Bassi, A.; Heitel, M. Facilitating the incorporation of VIP into precast concrete sandwich panels. Energy Build. 2014, 85, 666-671. [CrossRef]

28. Yun, S.; Jung, W. Benchmarking sustainability practices use throughout industrial construction project delivery. Sustainability 2017, 9, 1007. [CrossRef]

29. Steinhardt, D.A.; Manley, K. Adoption of prefabricated housing-the role of country context. Sustain. Cities Soc. 2016, 22, 126-135. [CrossRef]

30. Blismas, N.; Pasquire, C.; Gibb, A. Benefit evaluation for off-site production in construction. Constr. Manag. Econ. 2006, 24, 121-130. [CrossRef]

31. Zhao, X.; Hwang, B.; Gao, Y. A fuzzy synthetic evaluation approach for risk assessment: A case of Singapore's green projects. J. Clean. Prod. 2016, 115, 203-213. [CrossRef]

32. Hwang, B.; Shan, M.; Phua, H.; Chi, S. An exploratory analysis of risks in green residential building construction projects: The case of Singapore. Sustainability 2017, 9, 1116. [CrossRef]

33. Arashpour, M.; Wakefield, R.; Blismas, N.; Minas, J. Optimization of process integration and multi-skilled resource utilization in off-site construction. Autom. Constr. 2015, 50, 72-80. [CrossRef] 
34. Rahman, M.M. Barriers of Implementing Modern Methods of Construction. J. Manag. Eng. 2014, 30, 69-77. [CrossRef]

35. Arashpour, M.; Wakefield, R.; Blismas, N.; Maqsood, T. Autonomous production tracking for augmenting output in off-site construction. Autom. Constr. 2015, 53, 13-21. [CrossRef]

36. Polat, G. Factors Affecting the Use of Precast Concrete Systems in the United States. J Constr. Eng. 2008, 134, 169-178. [CrossRef]

37. Hwang, B.G.; Zhao, X.; Van Do, T.H. Influence of trade-level coordination problems on project productivity. Proj. Manag. J. 2014, 45, 5-14. [CrossRef]

38. Asri, M.; Nawi, M.; Saad, R.; Wan, N.O.; Anuar, H.S. Exploring lean construction component for Malaysian industrialized building system logistics management-A literature review. Adv. Sci. Lett. 2016, 22, 1593-1596. [CrossRef]

39. Pan, W.; Sidwell, R. Demystifying the cost barriers to offsite construction in the UK. Constr. Manag. Econ. 2011, 29, 1081-1099. [CrossRef]

40. Khalili, A.; Chua, D.K. Integrated Prefabrication Configuration and Component Grouping for Resource Optimization of Precast Production. J. Constr. Eng. Manag. 2014, 140, 1-12. [CrossRef]

41. Jaillon, L.; Poon, C.S. Sustainable construction aspects of using prefabrication in dense urban environment: A Hong Kong case study. Constr. Manag. Econ. 2008, 26, 953-966. [CrossRef]

42. Polat, G. Precast concrete systems in developing vs. industrialized countries. J. Civ. Eng. Manag. 2010, 16, 85-94. [CrossRef]

43. David, G.; Edward, B.; Nahid, H. Influence of Risk and Change Events on Cost, Schedule, and Predictability Performances. J. Prof. Issues Eng. Educ. Prac. 2016, 142, 1-9.

44. Poirier, E.A.; Staub-French, S.; Forgues, D. Measuring the impact of BIM on labor productivity in a small specialty contracting enterprise through action-research. Autom. Constr. 2015, 58, 74-84. [CrossRef]

45. Kim, Y.; Han, S.; Yi, J.; Chang, S. Supply chain cost model for prefabricated building material based on time-driven activity-based costing. Can. J. Civ. Eng. 2016, 43, 287-293. [CrossRef]

46. Jaillon, L.; Poon, C.S. The evolution of prefabricated residential building systems in Hong Kong: A review of the public and the private sector. Autom. Constr. 2009, 18, 239-248. [CrossRef]

47. Hill, R.C.; Bowen, P.A. Sustainable construction: principles and a framework for attainment. Constr. Manag. Econ. 1997, 15, 223-239. [CrossRef]

48. Winch, G. Models of manufacturing and the construction process: The genesis of re-engineering construction. Build. Res. Inf. 2003, 31, 107-118. [CrossRef]

49. Alazzaz, F.; Whyte, A. Linking employee empowerment with productivity in off-site construction. Eng. Constr. Arch. Manag. 2015, 22, 21-37. [CrossRef]

50. Matic, D.; Calzada, J.R.; Eric, M.; Babin, M. Economically feasible energy refurbishment of prefabricated building in Belgrade, Serbia. Energy Build. 2015, 98, 74-81. [CrossRef]

51. Gann, D. Putting academic ideas into practice: Technological progress and the absorptive capacity of construction organizations. Constr. Manag. Econ. 2010, 19, 321-330. [CrossRef]

52. Shan, Y.; Imran, H.; Lewis, P.; Zhai, D. Investigating the latent factors of quality of work-life affecting construction craft worker job satisfaction. J. Constr. Eng. Manag. 2017, 143, 1-10. [CrossRef]

53. Qian, Q.; Chan, E.; Khalid, A. Challenges in Delivering Green Building Projects: Unearthing the Transaction Costs (TCs). Sustainability 2015, 7, 3615-3636. [CrossRef]

54. Zhong, R.Y.; Peng, Y.; Xue, F.; Fang, J.; Zou, W.; Luo, H.; Thomas Ng, S.; Lu, W.; Shen, G.Q.P.; Huang, G.Q. Prefabricated construction enabled by the internet-of-things. Autom. Constr. 2017, 76, 59-70. [CrossRef]

55. Xue, H. Factors Affecting the Capital Cost of Prefabrication. Available online: https://sojump.com/jq/ 12604390.aspx (accessed on 23 August 2017).

56. Hwang, B.G.; Zhao, X.; Ong, S.Y. Value management in Singaporean building projects: Implementation status, critical success factors, and risk factors. J. Manag. 2015, 31, 4014091-4014094. [CrossRef]

57. Kwofie, T.E.; Alhassan, A.; Botchway, E.; Afranie, I. Factors contributing towards the effectiveness of construction project teams. Int. J. Constr. Manag. 2015, 15, 170-178. [CrossRef]

58. Zainul Abidin, N. Investigating the awareness and application of sustainable construction concept by Malaysian developers. Habitat Int. 2010, 34, 421-426. [CrossRef]

59. Hwang, B.G.; Zhao, X.; See, Y.L.; Zhong, Y. Addressing risks in green retrofit projects: The case of Singapore. Proj. Manag. J. 2015, 46, 76-89. [CrossRef] 
60. Correia, I.; Saldanha-da-Gama, F. The impact of fixed and variable costs in a multi-skill project scheduling problem: An empirical study. Comput. Eng. 2014, 72, 230-238. [CrossRef]

61. Arifa, F.; Lodib, S.H.; Azhar, N. Factors influencing accuracy of construction project cost estimates in Pakistan: Perception and reality. Int. J. Constr. Manag. 2015, 15, 59-70. [CrossRef]

62. Pan, W.; Gibb, A.G.F.; Dainty, A.R.J. Leading UK housebuilders' utilization of offsite construction methods. Build. Res. Inf. 2008, 36, 56-67. [CrossRef]

63. Xin, H.; Bo, X.; Kunhui, Y.; Martin, S. Underlying knowledge of construction management consultants in China. J. Prof. Issue Eng. Educ. Pract. 2015, 142, 1-9.

64. Chan, A.P.C.; Darko, A.; Ameyaw, E.E. Strategies for promoting green building technologies adoption in the construction Industry-An international study. Sustainability 2017, 9, 969. [CrossRef]

65. Jarkas, A.M. Factors influencing labour productivity in Bahrain's construction industry. Int. J. Constr. Manag. 2015, 15, 94-108. [CrossRef]

66. Gao, S.; Low, S.P. Toyota way style human resource management in large Chinese construction firms: A qualitative study. Int. J. Constr. Manag. 2015, 15, 17-32. [CrossRef]

67. Chan, A.P.C.; Hu, Y.; Ma, L.; Shan, M.; Le, Y. Improving the Outcomes of Public Drainage Projects through NEC3-Based Relational Contracting: Hong Kong Case Study. J. Prof. Issue Eng. Educ. Pract. 2015, 142, 1-3. [CrossRef]

68. Xue, X.; Zhang, X.; Wang, L.; Skitmore, M.; Wang, Q. Analyzing Collaborative Relationships among Industrialized Construction Technology Innovation Organizations: A Combined SNA and SEM Approach. Available online: http://www.sciencedirect.com/science/article/pii/S0959652617300094 (accessed on 23 August 2017).

(C) 2017 by the authors. Licensee MDPI, Basel, Switzerland. This article is an open access article distributed under the terms and conditions of the Creative Commons Attribution (CC BY) license (http:/ / creativecommons.org/licenses/by/4.0/). 